\title{
有限要素法の事後誤差評価結果を利用した 順応型要素分割法に関する研究
}

\author{
正員大 坪 英 臣正員 久保田 晃 弘 \\ 北村充
}

A Study on Adaptive Mesh Generation for the Finite Element Method Using A Posterior Estimated Error

by Hideomi Ohtsubo Member, Akihiro Kubota Member Mitsuru Kitamura

\section{Summary}

Adaptive mesh generation using a posteriori error estimation has recently attracted great interest. This paper proposes a new $r$-method of adaptive mesh generation for the finite element method. The objective function of this method is to minimize the error norm of the whole computational domain. It is very impotant for the adaptive mesh generation to estimate the numerical error accurately. The discretization error in the finite element method is estimated using the computer code ERRAND-FEM ${ }^{8)}$ developed by the authors.

In order to verify the newly proposed adaptive method, we have chosen two 2-dimensional stress concentration and singularity problems. The results show the validity and the effectiveness of this method. Since this method is very simple and flexible, it is quite possible to extend it to any other problems, such as shell problems or solid problems.

\section{1. はじめに}

この数十年の間に飛躍的な進歩を遂げた有限要素法は, 現在では工学分野を中心に多くの方面で日常的な数値計算 ツールとして使われている。しかしながらよく知られてい るように, 有限要素解の信頼性はそのモデル化の良否に大 きく依存する。どのようなモデル化をしてもとにかく数值 解は得られるが，その解が物理的に妥当であるためには， 正しいモデル化を行う必要がある。一般に有限要素法の解 の信頼性は高いといわれているが，それはモデル化が正し く行われた場合に限られる。

最近のように大規模で複雑な構造の解析を行うようにな ってくると, コストの大部分は計算そのものよりも入力デ 一夕の作成や出力データの整理に費やされる。特に前述の ように数值解の信頼性と密接な関係がある入力データ，す なわち有限要素モデルの作成の省力化, 自動化は特に重要 な課題である。

現在物理的な妥当性をあまり考慮しなければ, いくつか

東京大学工学部船舶海洋工学科
の汎用の有限要素モデル自動作成プログラムが存在する。 また一方，モデル作成の際には「応力集中部は細かい要素 分割にする」ということはよく知られており，このことを 考慮して自動的にモデル作成を行う試みも行われている 1,2)。しかしながら, 解析する以前に応力分布をある程度正 確に知るためにはかなりの経験を積む必要性がある。また, それでも要素をどの程度細かくするかを定量的に判断する のは非常に困難である。もし, 数值解の誤差の分布がわか れば，その結果を利用して最初の分割を修正し，より精度 の高い解を得ることができる。

一般に, 一度解析を行った後その結果を用いて「数值解 の誤差をできるだけ小さくするように」要素分割の仕方を 変えていくことを, 順応型要素分割 (adaptive mesh generation) という。具体的にはモデルのある部分の誤差が大き いと判断されたとき, その部分の要素分割が細かくなるよ うに修正して, 再度解析を行うことである ${ }^{3.4,5)}$ 。この順応型 要素分割法には Fig. 1 に示すような 3 つの方法がある。

(1) $r$-method

(2) $h$-method

( 3 ) $p$-method 
(a)original mesh

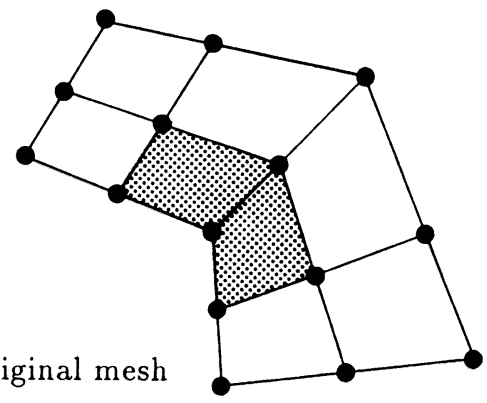

(b)r-method

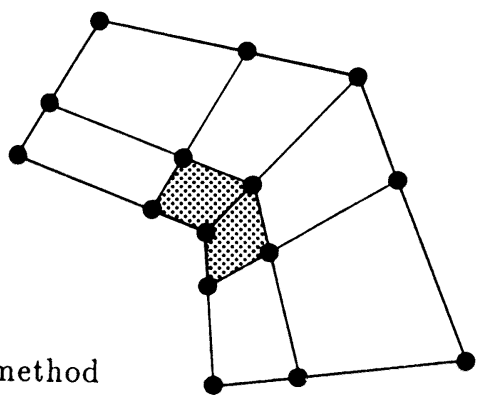

(c)h-method

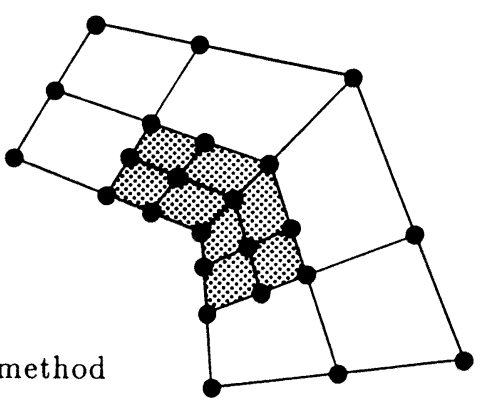

(d)p-method

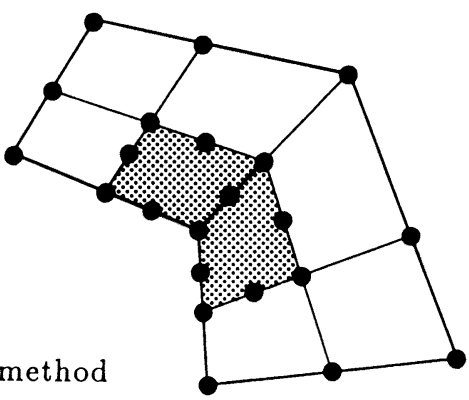

Fig. 1 Adaptive mesh generation

$r$-method は要素数および節点数を変えずに節点の座標だ けを変化させる方法である(Fig. 1(b))。モデルの要素数, 節点数は変化しない。 $h$-method は誤差の大きい部分の要 素をさらに細かく分ける方法, つまり要素の代表寸法 $\mathrm{h}$ を 変化させる方法である (Fig. 1(c))。この方法ではモデル の要素数, 節点数が増加する。 $p$-method は誤差の大きい領 域の要素を, 内插関数の次数がより高次の新しい要素に置 き換える方法である (Fig. 1(d))。ここでは要素の分割形
状は変化しないが自由度数は増加する。

本論文は， $r$-methodによる新しい順伈型要素分割法を 提案し，その妥当性，有効性を検証したものである。特に その目的関数と詳細な手法を明示し，その方法ができるか ぎり普遍性を有するようにすることを，開発に際しての 1 つの大きな目標とした。そして，CAD/CAEといった設計 自動化システムの一環として用いることを念頭においたの で，そのアルゴリズムがなるべくシンプルになるように心 がけた。アルゴリズムがシンプルであることはとりもなお さずそのシステムが高速でフレキシビリティに富むことを 意味する。さらに再分割の際に，モデル毎に異なる值をと るパラメータを用いないように留意した。このことにより 「応力集中部は細かい要素分割にする」といった定性的, 経 験的な知識に対して，パラメータをモデル毎にコントロー ルすることなく，直接「どの程度細かくすれば良いのか？」 という定量的，客観的な情報を与えることが可能になる。 これは真の自動化システムを構成するためには，ぜひとも 必要とされる条件である。

順応型要素分割を用いてより良い有限要素モデルを作成 するためにはまず数值解の誤差の分布・大きさを正確に知 ることがもっとも重要である。しかしながら従来の様々な 順応型要素分割法では，そのもつとも基本となるべき誤差 評価の精度が不十分であったために，その結果に物理的妥 当性を欠くものが実に多い。そこで, 本研究では数值解の 誤差は著者らが開発した有限要素法事後誤差評価プログラ

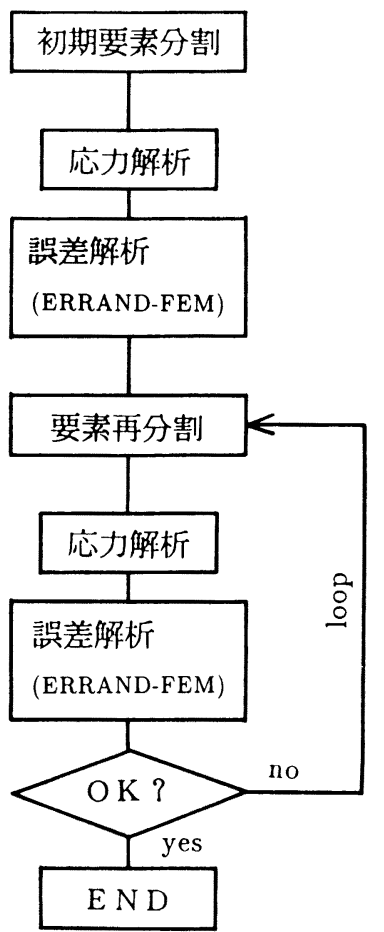

Fig. 2 Flow of adaptive mesh generation 
ムERRAND-FEM を用いて解析した ${ }^{6.7 .8)}$ 。これは有限要 素解の離散化䛊差を元の解析に用いた要素の形状関数の次 数より1次高い要素を用いて要素ごとに解析するものであ る。このERRAND-FEM を用いることによって, 全領域 な゙けでなく，各要素レベルでも十分な精度で定量的な事後 䛊差評価が可能になることが確かめられている。Fig. 2 に ERRAND-FEM を用いた順忍型要素分割のアルゴリズム を示す。

\section{2. 順応型要素分割のコンセプト}

順応型要素分割の目的は「数値解の䛊差をなるべく小さ くすること」である。そこで本研究では順応型要素分割の 目的関数を解析領域全体の誤差のエネルギーノルム $\|e\|$ と し，こ机を最小にすることを目的にする。な㧍，r-method を用いた場合要素抽よび節点の数とトポロジーを変化させ ないことが要素分割の際の制約条件になる。

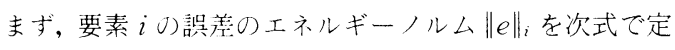
義する。

$$
\|e\|_{i}^{2}=\int_{S_{i}} \nabla^{\prime} e \cdot E \nabla^{\prime} e d \Omega
$$

ここで, $E$ 弾性係数テンソル，eは変化ベクトルuの䛊 差, そして浪は変位一ひずみオペレータである。応力テン

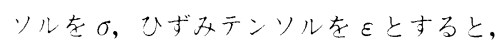

$$
\sigma=E \varepsilon=E \nabla^{\prime} u
$$

つ関係が成り立つ。したがって解析全領域の誤差の工ネル ギーノルム $\|e\|$ 㳉次式で与えられる。

$$
\|e\|^{2}=\sum_{i=1}^{N}\|e\|_{i}^{2}
$$

ここで $N$ は全要素数である。

\section{3. 順応型要素分割のストラテジー}

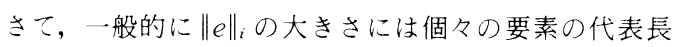
き, 形状, 近似関数の次数など, そしてモデルの制約条件 が複雑に関係している。したがって, 前章で定義した目的 関数, すなわち解析領域全体の誤差のエネルギーノルム $\|e\|$ を最小にするような要素分割を直接求めることは非常 に困難である。ところが, 要素面積の総和が一定の場合 $\|e\|^{2}$ 在小さく寸ることは要素毎の誤差のエネルギーノルムの 2 乗 $\|e\|_{i}^{2}$ を要素によらず一定にすること

$$
\|e\|_{i}^{2}=\text { constant }
$$

$$
\text { すなわち }
$$

$$
\|e\|_{i}=\text { constant }
$$

と同値である 9,111)。そこで, 本論文では「各々の要素の誤差 のエネルギーノルムが等しくなるように節点を移動させ る」ことを考える。

\section{4. 節点の移動方法}

各要素の誤差は「要素代表長さ」と「要素形状」の 2 つ ひハランータに支配される。このうち「要素代表長さ」が
定量的に評価することの容易なパラメータであるのに対 し,「要素形状」は定量的に評価することが困難なパラメー 夕である。そこでまず「要素代表長さ」による要素の誤差 の変化を考慮して節点を移動することを考える。基本的に は相対的に誤差の大きい要素の代表長さが小さくなるよう に節点が移動すれば良いのであるから，本論文では第 1 章 で示した設計自動化システムの一環として使用するための 条件を満たす節点移動方法として, 次のような反復方法を 採用する。

「ある節点をその節点を含むすべての要素の重心位置に 要素の誤差の大きさに応じた重みをかけた平均の位置に移 動させる。」」)

すなわち

$$
r_{n}^{m+1} \longleftarrow \frac{\sum_{k}\left(W_{k}^{m} \cdot R_{k}^{m}\right)}{\sum_{k} W_{k}^{m}}
$$

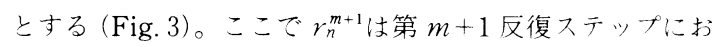
ける節点 $n$ の位置ベクトル, $R_{k}^{m}$ は第 $m$ ステップに扔ける 節点 $n$ を含要素 $k$ の重心位置, そして $W_{k}^{m}$ が第 $m$ ステ ップに扔ける要素 $k$ の重みである。

重みWは各ステップにおける要素毎の誤差のエネルギ 一ノルムとする。各反復ステップ毎に要素形状が変化寸る のでこの重みを正確に求めるためには各ステップ毎に毎回 忘力解析ならびに誤差解析を行う必要がある。しかし設計 自動化システムの基本コンセプトの主旨からいっても, も つと一般的な工学的センスからいっても毎回㛜密な䛊差解 析を行うことははなはな゙非効率的である。そこで, 節点移 動反復ステップ中の要素毎の誤差, すなわち重み $W$ は誤 差のエネルギーノルムの初期值 $\|e\|_{i}^{0} を も と に$, 要素代表長 さの変化によって事前誤差解析 ${ }^{11)}$ 加簡便に推定される誤 差ノルムの予測值を用いることにする。したがって本方法 では新たに, 第 $m$ 反復ステップ中の要素 $i の$ 重み $W_{i}^{m}$ を 次式で与えることにした。

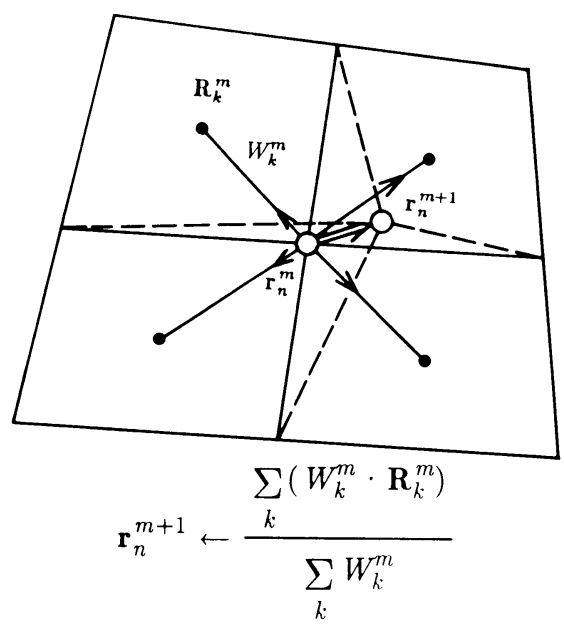

Fig. 3 Method of node movement 


$$
W_{i}^{m}=\|e\|_{i}^{0} \cdot\left[\frac{h_{i}^{m}}{h_{i}^{0}}\right]^{p+1-n} \cdot\left[\frac{h_{i}^{m}}{h_{i}^{0}}\right]^{\frac{D}{2}}
$$

ここで $p$ は要素の内捰関数の次数, $D$ はモデルの次元であ る。 $n$ は誤差ノルムの微分階数であり,ここでは $n=1$ であ る。また $h_{i}^{0}$ は要素代表長さの初期值であり, $h_{i}^{m}$ は第 $m$ 反 復ステップにおける要素代表長さである。 $D=2$ の場合, 要 素代表長さ $h$ は要素面積の平方根とし, $D=3$ の場合, $h$ は 要素体積の立方根とする。このとき, $\left[h_{i}^{m} / h_{i}^{0}\right]^{p+1-n}$ の項は要 素代表長さの変化により事前誤差解析から予測される単位 面積あたりの誤差の変化率であり, $\left[h_{i}^{m} / h_{i}^{0}\right]^{\frac{D}{2}}$ の項は要素面 積の変化による要素全体の誤差の変化率である。なお, 要 素代表長さの変化による項の $p$ の值は要素が特異点を含 む場合にはその特異点の性質に応じて修正する必要があ る。

以上のような方法で節点移動の際の重み $W$ を変化させ ることにより，本方法では初期分割およびその誤差分布が 与えられればその再分割結果は反復過程を通じて一義的に 決定されることになる。このように結果が決定的，すなわ ち自動的に得られることが本順応型要素分割法の大きな特 色である。

次に「要素形状」による項について考える。一般的にた とえ要素の代表長さが等しくても，要素の形状が歪むにつ れてその誤差が増加することはよく知られている。しかし この「要素形状」の良否を定量的に表現し, 要素誤差の増 減と定量的に結び付けることが可能な値というものは現在 のところ存在しない。そこで, 本論文ではこの「要素形状」 に関しては「メッシュをなるべくスムーズにする」という コンセプトで要素代表長さの影響とは独立にあくまで「定 性的に」そして「補助的に」考慮することにする。このス ムージングは児玉の方法 ${ }^{12)}$ を参考にして, 以下のように行 う。

「ある節点の位置を，その節点と接続しているすべての 節点に節点間の距離に反比例した重みをかけて平均化した 位置に移動する。」

すなわち, Fig. 4 に示すように $k$ を節点 $n$ と接続している 節点とするとスムージング後の節点 $n$ の位置 $r_{n}$ は次式で 与えられる。

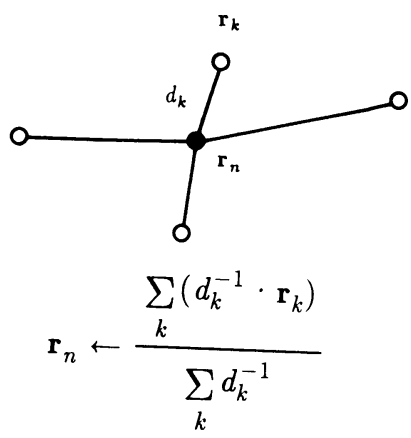

Fiq. 4 Smoothing

$$
r_{n} \leftarrow \frac{\sum_{k}\left(d_{k}^{-1} \cdot r_{k}\right)}{\sum_{k} d_{k}^{-1}}
$$

ここで， $r_{k}$ は節点 $k$ の位置， $d_{k}$ 節点 $n$ と節点 $k$ の距離で ある。節点間の距離に反比例した重みをかけない単純な平 均化によるスムージングと比較して，このす法はスムージ ングの効果が節点の密な方向にだけ選択的に働くので'2), 有限要素モデルの場合にも効果的である。なお，（6)式で 示される節点移動の際にもある節点を含む要素の重みが等 しくなってくると通常のラプラシアン法 ${ }^{13)} に$ 類似したスム ージング効果が現れてくる。

\section{5. 節点移動の境界条件}

節点が有限要素モデルの境界にある場合，節点を移動さ せる際にはモデルの形状を変化させないように節点の移動 に制約を設けなければならない。この節点移動の境界条件 については, モデルが 2 次元の場合，境界条件を以下の 2 つに分類できる。

(1) 節点は移動させない。

（2）節点をある曲線上でのみ移動させる。

（1）はモデルのコーナーに存在する節点，あるいはクラッ クのチップに存在するような節点に適用される境界条件で ある。（2）はその他のモデル境界上に存在する節点に適用 される境界条件である。なお，モデルが 3 次元の場合には

(1)と（2)の条件に加えて

( 3 ) 節点をある曲面上でのみ移動させる という境界条件を加えれば良い。

次に(2)の境界条件を満足させる方法について説明寸 る。ここではまず，モデルの境界形状に関する情報はオリ ジナルの有限要素モデルの節点位置のみから与えられるも のとし，その他の，曲線の方程式等の付加的な情報は用い ないものとする。前章で示した節点の移動方法では，1回 の節点移動のプロシージャーにおいてはその節点がその節 点を含む要素の重心位置で形成される多角形の外部に移動 しないことがわかる。そこで，モデル形状はある境界上の 節点とそれに接続している $2 つ の$ 境界節点の合計 3 点で決 定される 2 次曲線上を移動するものとした。この方法では, 境界節点がモデル境界のコーナー部に存在する場合が問題 となるが，r-methodを用いた要素再分割の場合コーナー 部の節点には（1）の境界条件を課するので，特に不都合は 生じない。

具体的には以下のような手順で境界節点を移動させる。 まず，境界条件を考慮せずに前章で示した方法にしたがつ て節点を移動させる。この後に Fig. 5 に示した方法で節点 をモデル境界上に移動させる。すなわち $r_{c}, r_{t}$ を今注目し ている境界上節点の移動前および境界条件を考慮せずに移 動させた後の位置とし， $r_{l}, r_{r}$ をその節点と接続している 境界上節点の位置とすると，モデルの境界上に移動した後 


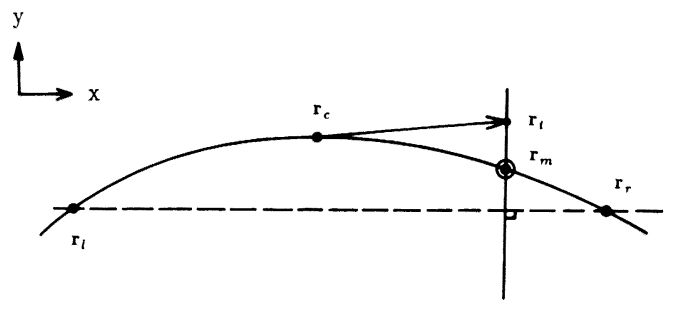

Fig. 5 Arbitrary boundary condition

の節点位置 $r_{m}$ は $r_{l}, r_{c}, r_{r}$ の 3 点で決定される 2 次曲線 と， $r_{l}$ から $r_{l}$ と $r_{r}$ を結ぶ直線上に扔した垂直との交点 のうち $r_{t}$ に近い方の点とする。この方法は近似的ではある が計算時間が短く，しかもいかなる場合でも值が一意に決 定する。な扔，この方法の場合要素形状が急激に変化する 部分で節点どうしが離れている場合に精度が低下寸るが, 少なくともモデル形状をある程度正確に表現できる程度の 節点が境界上に存在する場合, 特に問題は生じないと考え られる。

以上示した「節点移動」,「スムージング」,「境界条件」 の各方法を用いることによって, 実際の要素再分割は Fig. 6のアルゴリズムで計算が収束するまで行われる。なお, 以 上の説明に用いた Fig. 3 およびFig. 4 は 4 節点の平面要 素を念頭において描かれているが，8 節点の平面要素のよ うに要素のコーナー以外に節点が存在する場合でも, 要素 のコーナー部に存在する節点のみ以上の手順で移動させ, その他の節点についてはコーナー部の節点位置から補間し て求めれば良い。さらに, 本方法は 3 角形要素あるいは 3 次元要素等にもそのまま適用可能である。したがって, 本 方法の特徵として以下の 4 点をあげることができる。

(1) 結果が一義的に得られる。

（2）モデルの次元によらない

（3）任意の要素の組み合わせに対して適用可能である

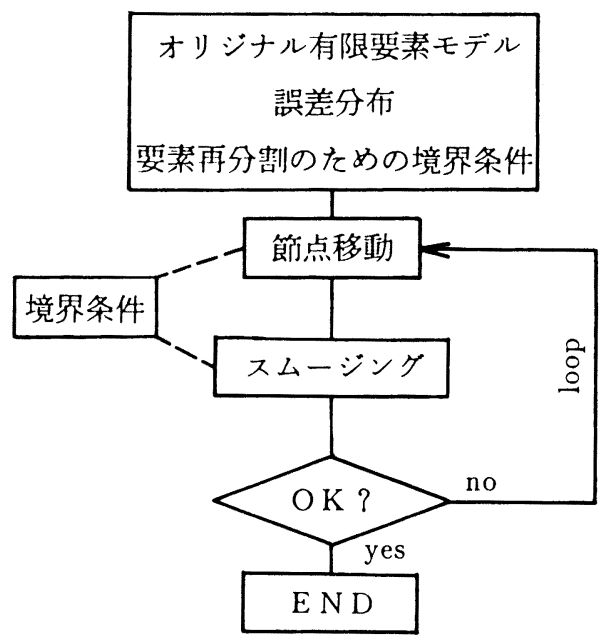

Fig. 6 Flow of node relocation
（4）計算時間が短い

それでは次に本順応型要素分割法の妥当性・有効性をい くつかの例題を用いて示していくことにしよう。

\section{6. 順応型要素分割の適用例}

\section{1 円孔を有する正方形板}

本論文では 2 次元の平面応力問題を考える。今, Fig. 7(a)のように半径 $\mathrm{a}$ の円孔を有する正方形板がその 2 辺 に一様張力 $s$ を受けているとする。数值パラメータは次の ように設定した。

$$
a=2 \quad b=8 \quad s=1 \quad E=10000 \quad \nu=0.3
$$

ここで $E$ はヤング率, レはポアソン比である。対称性を考 慮して, Fig. 7( b ) のような 1/4の領域を解析する。この 1/ 4 領域に対して，まず Fig. 8 に示すような 4 節点要素で構 成される 3 種の有限要素モデル $(M E S H-A, B, C)$ を初期 モデルとして数值解析を行う。これらはいずれも円孔周辺 の応力集中などを考慮せずに各辺を等分割することによっ

$$
\begin{aligned}
& E=10000 \\
& \nu=0.3 \\
& a=2 \\
& b=8 \\
& \mathrm{~S}=1
\end{aligned}
$$

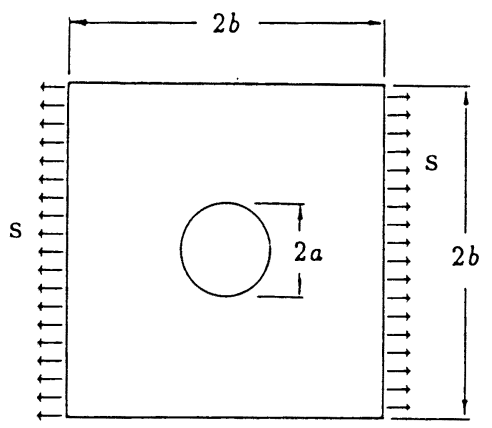

(a)

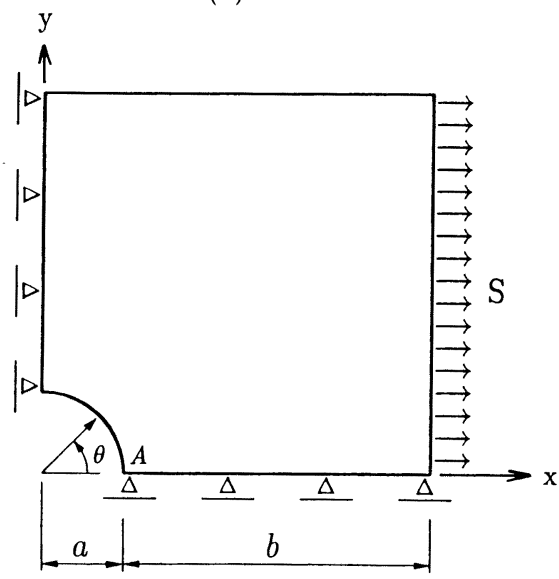

(b)

Fig. 7 Square plate with a hole 


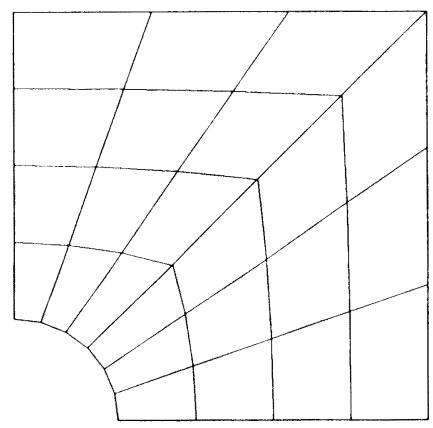

MESH-A (coarser) 24 Elements 35 Nodes

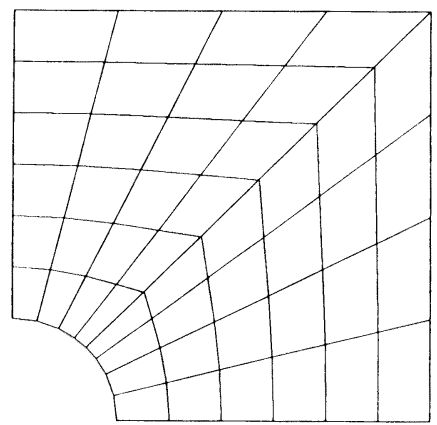

$M E S H-B($ medium) 48 Elements 63 Nodes

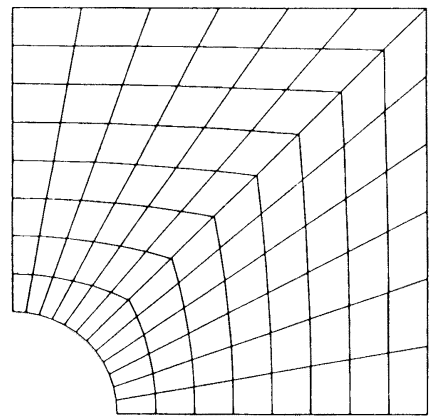

MESH-C(finer)

96 Elements

117 Nodes

Fig. 8 Three original finite element models

て得られたものである。

$M E S H-A, B, C$ の要素数の比は $1: 2: 4$ で, MESH-C は $M E S H-A の 1$ 要素をさらに 4 分割したものとなって いる。な扔，この 4 節点一次要素の誤差ノルムの収束は $O(h)$ であるので，（７)式におけるpの值は 1 となる。

要素再分割の際の境界条件として, コーナ一部の節点に 対しては前章の（1）の節点固定の境界条件を適用し，その 他の有限要素モデル境界上の節点に対しては，（2）のモデ ル境界上のみを節点移動させる境界条件を適用する。

まず, Fig. 2 のアルゴリズムに示されているように,この 初期有限要素モデルに対して応力解析ならびに ERRAND -FEM を用いた誤差解析を行った。Table 1 に各 MESH$A, B, C$ を用いた場合の領域全体の相対誤差 $\|e\| /\|u\|$ なら びに $\sigma_{x}$ の最大值 $\left(\sigma_{x}\right)_{\max }$ の值を示す。ここで\|u\|は領域全 体での変位のエネルギーノルムである。この結果から，円 孔近傍の応力集中を考慮せずに有限要素モデルを作成する
と，もっとも細かい MESH-C を用いた場合でも，相対䛊 差の大きさは $15.6 \%$ にもなことがおかる。また， $\sigma_{x}$ が最 大になるのはいずれも $\theta=90 \mathrm{deg} .0$ 円節点である。

Fig. $\ddot{9}$ は $M E S H-B$ を用いた場合の, 要素毎の誤差の工 ネルギーノルム $\|e\|_{i}$ の分布である。 $\|_{i}$ は応力の集中する 円孔近傍で極端に大きくなっている。なお，変位のエネル ギーノルムがもつとも大きくなるのは円孔近傍の中でも特 に $\theta=90 \mathrm{deg}$. 周辺であるが, 誤差のエネルギーノルムが最 大になるのは， $\theta=90 \mathrm{deg}$. の周辺ではなくせん断応力の大 きくなる $\theta=45 \mathrm{deg}$. 周辺である。これはここで用いた 4 節 点要素のせん断応力に対する誤差が直応力の誤差よりも大 きいためであると考えられる。この結果から，より適切な 要素分割を行うための誤差解析の重要性が再確認される。

さて,この誤差解析結果を用いて要素再分割を行った結 果を示す前に, 本順応型要素分割法の収束性をチェックし ておこう。Fig. 10 は Fig. 6 に示す反復ステップにおける節 点移動距離の収束率を $M E S H-B$ の場合について示した ものである。ここで, 縦軸は全節点に打ける節点移動距離 $\Delta d$ の 2 乗平均の無次元值 $\sqrt{\Sigma} \Delta d^{2} / L$ である。なお $L$ は平均 的な要素代表長さ,すなわち $\sqrt{(\text { 解析領域の面積 }) /(\text { 要素数 })}$ である。この図から本方法の収束率の高さがわかる。本論 文では要素再分割の収束判定を

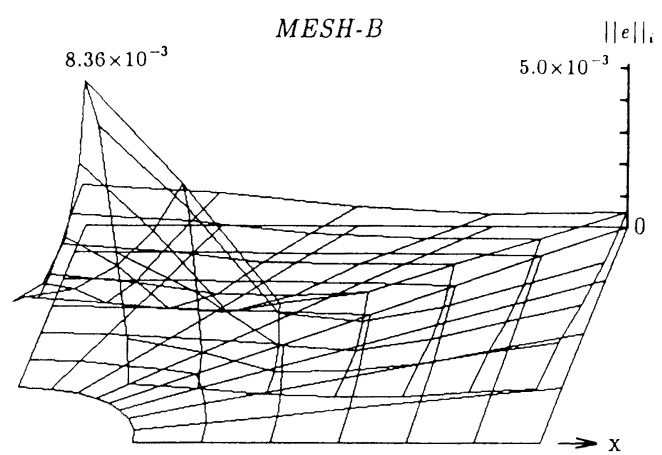

Fig. 9 Estimated error distribution for the original mesh

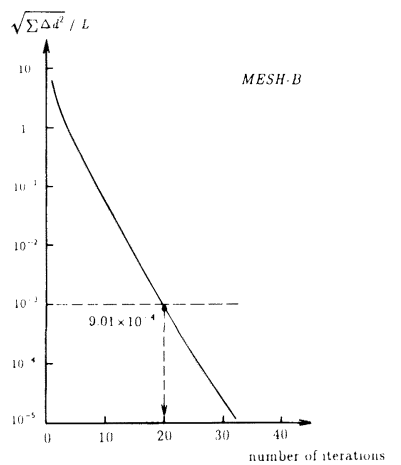

Fig. 10 Convergence of node movement 


$$
\sqrt{\Sigma \Delta d^{2}} / L<1.0 \times 10^{-3}
$$

としたので, この場合 20 回の反復で収束したと判定され た。前述のように本方法の計算時間は非常に短いため, 20 回反復を行ったとしても, 要素再分割に必要な計算時間は 応力解析に必要な計算時間の $1 / 10$ 以下である。

Fig. 11 は節点移動の際に用いた要素毎の重み $W_{i}$ の 2 乗和の反復回数における変化を, 同じく $M E S H-B$ の場合 についてプロットしたものである。ここで重み $W_{i}$ は各要 素の節点移動後の予測誤差ノルムに相当するので, この図 の縦軸は節点移動後の全領域における予測誤差ノルムの 2

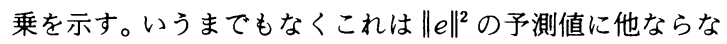
い。この結果からも本節点移動法により, 領域全体の誤差 が確実に減少することが確認される。また，収束判定によ り 20 回で反復を打ち切った場合でも, 100 回反復を行った 場合と比較して $W_{i}$ の 2 乗和はたかだかその $1.4 \%$ しか異 ならないことがわかる。さらに, 20 回反復を行った場合, この要素再分割によって領域全体の誤差のエネルギーノル 厶 $\|e\|$ が約 $\sqrt{5.08 \times 10^{-3} / 1.60 \times 10^{-2}}=0.563$ 倍に減少する ことが予測される。

Fig. 12 は初期有限要素モデル $(M E S H-A, B, C)$ に対 して, Fig. 2 に示す手順で順応型要素分割を行った結果 $(M E S H-D, E . F)$ である。ここで, 要素再分割は 1 回のみ 行い, Fig. 2 に示すloop は回していない。いずれのモデル についても応力の集中する円孔近傍に節点が集中している ことがわかる。また，円孔から遠ざかる方向にほぼ同心円 上に節点が並ぶことがわかる。

この $M E S H-D, E, F$ に対して ERRAND-FEMを用 いて誤差解析を行った結果ならびに $\sigma_{x}$ の最大值を Table 1 に示す。初期有限要素モデル $M E S H-A, B, C$ に比較し て誤差は大幅に隇少しており，もっとも細かい要素分割の $M E S H-F$ の場合 $M E S H-C$ に比べて相対誤差が 0.436 倍に減少した。また，もっとも粗い $M E S H-D$ の場合でも 相対誤差は $14.2 \%$ であり,これは要素数が 4 倍の $M E S H-$ $C$ に比較してもさらに小さい。この結果が順応型要素分割 の有効性および重要性を端的に表している。もちろん $\sigma_{x}$ の最大值も要素を再分割することにより，いずれの場合に ついても再分割前より大きくなっている。Fig. 13 は

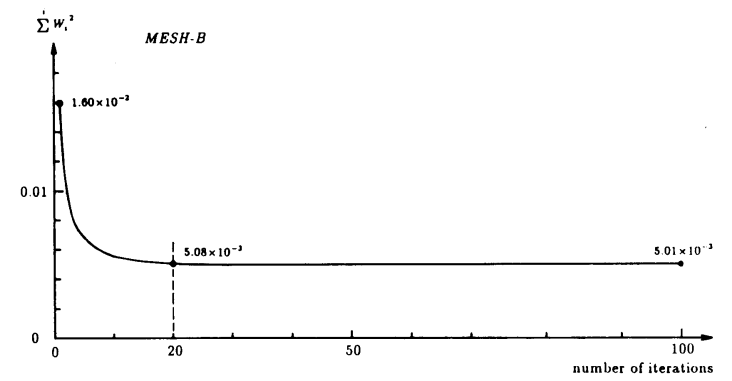

Fig. 11 Convergence of total weight

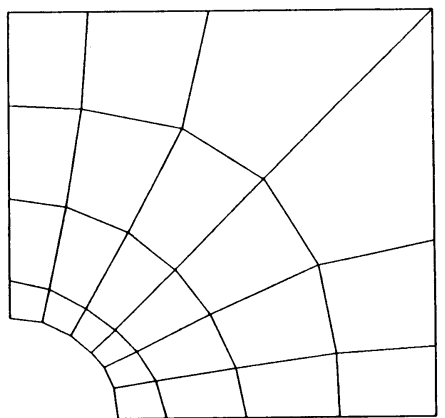

$M E S H-D$ (coarser) 24 Elements 35 Nodes

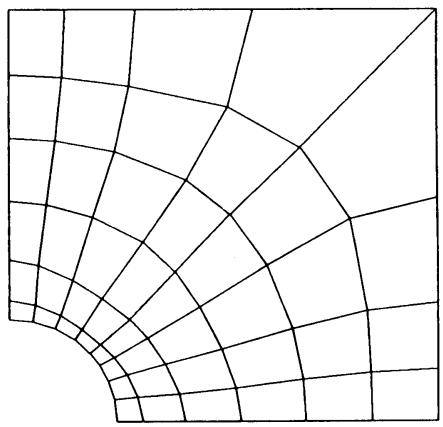

$M E S H-E$ (medium) 48 Elements 63 Nodes

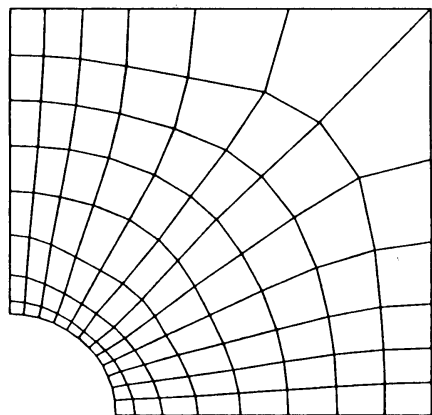

MESH-F(finer)

96 Elements

117 Nodes

Fig. 12 Three adapted finite element models

Table 1 Estimated relative error and maximum stress for the plate with a hole

\begin{tabular}{|c|c|c|c|}
\hline & & $\|e\| /\|u\|$ & $\left(\sigma_{\theta}\right)_{\max }$ \\
\hline \multirow{2}{*}{ (a)coarser meshes } & $M E S H-A$ (original) & $22.0 \%$ & 2.984 \\
\hline & $M E S H \cdot D($ adapted $)$ & $14.2 \%$ & 3.324 \\
\hline \multirow{2}{*}{ (b)medium meshes } & $M E S H-B$ (original) & $18.6 \%$ & 3.264 \\
\hline & $M E S H-E($ adapted) & $9.1 \%$ & 3.460 \\
\hline \multirow{2}{*}{ (c)finer meshes } & $M E S H-C$ (original) & $15.6 \%$ & 3.459 \\
\hline & MESH-F(adapted) & $6.8 \%$ & 3.575 \\
\hline
\end{tabular}

$M E S H-A$ と $M E S H-D$ とで $y$ 軸上の $\sigma_{x}$ の分布を比較し たものである。要素再分割後は $\sigma_{x}$ のピークが上昇しただ けではなく, 要素境界での応力のギャップも減少している ことがわかる。 


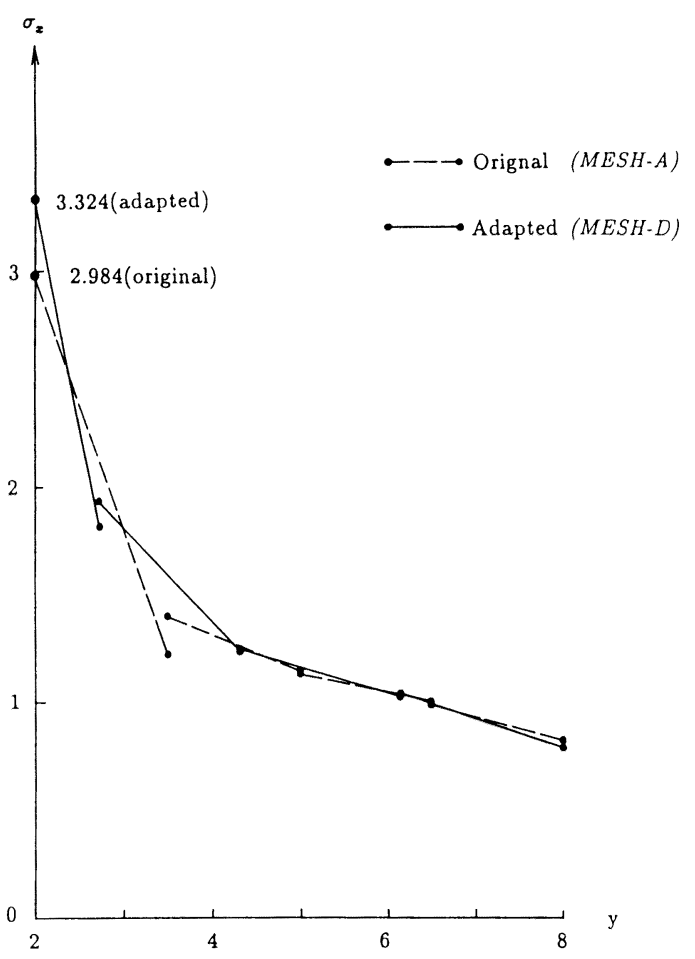

Fig. 13 Stress distributions along the $y$-axis

$M E S H-E$ の相対誤差の $M E S H-B$ との比は 0.489 で, 重みの予測值から推定した值に比較的よく一致している。 なお，MESH-B を再分割する際にFig. 6 の反復手順 100 回行っても, そのモデルの相対誤差は $9.0 \%$ であり, 反 復を 20 回で打ち切った場合とほほ同じである。また，スム ージングを行なわないと, 相対誤差は $9.5 \%$ となり（反復 20 回), スムージングを行った場合に比較して, 誤差はやや増 加する。

Fig. 14 は MESH-Eの場合について, 要素毎の誤差ノル ム $\|e\|_{i}$ の分布をプロットしたものである。Fig. 9 に比較し て \|\|$_{i}$ の分布は著しく平担化しており，一回の要素再分割 で当初の目的関数である(5)式がかなり良い精度で満足さ れていることがわかる。もちろん Fig. 2 の loop を繰り返 すことによって, 本例題の場合 $(5)$ 式はさらに厳密に満足 されていく。

本例題の最後に, 要素数の増加に対する誤差の収束率に ついて考察する。Fig. 15 は領域全体の要素数の平方根 $\sqrt{N}$ に対する領域全体の相対誤差\|e\|/\|u\|の変化をプロットし たものである。ここで, $\sqrt{N}$ はモデル全体の平均的な要素代 表長さ $L$ に反比例する。したがって事前誤差解析から, 本 例題の場合 $\|e\| /\|u\|$ は $\sqrt{N}$ の-1 乖に比例することが推定 される。この結果から，応力集中等の物理的な現象を考慮 せずに機械的に有限要素モデルを作成すると, 解の相対誤 差\|e\|/\|u\|が大きいだけでなく，その収束率も $\sqrt{N}$ の

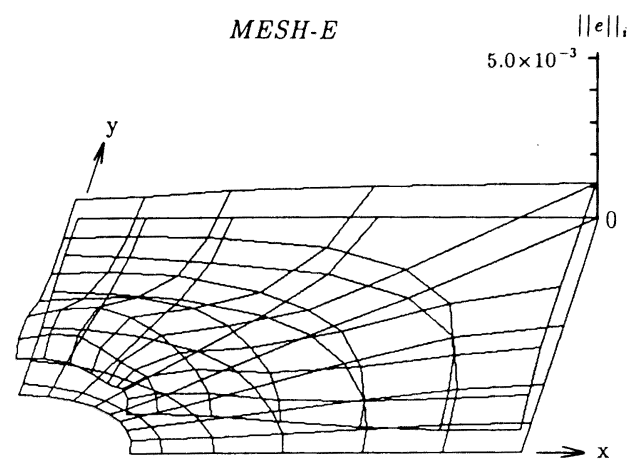

Fig. 14 Estimated error distribution for adapted mesh

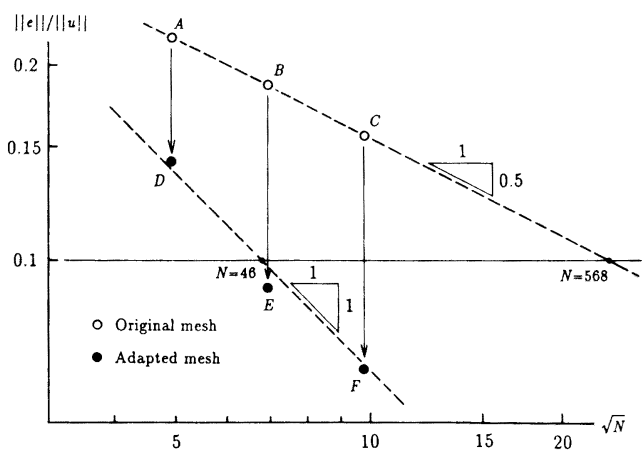

Fig. 15 Convergence of relative error

-0.5 乗と非常に悪くなることがわかる。しかもこの収束率 は事前詰差解析で予測されるものとは一致していない。そ して，例えば領域全体の相対誤差を $10 \%$ 以下に抑えようと すると，この機械的に作成されたモデルでは 500 以上もの 要素を必要とすることがわかる。それに対して本論文の方 法で得られた順応的な有限要素モデルを用いると相対誤差 の収束率は向上し， $\sqrt{N}$ の-1 乗と事前誤差解析から予測 されるものともほぼ一致する。また，同様に相対誤差を $10 \%$ 以下にするためには, おずかに 50 弱の要素で十分であ ることがわかる。

\section{2 クラックを有する正方形板（特異性のある問題）}

次に同様の 2 次元問題ではあるが，解析領域内に特異点 を含む場合を考える。有限要素法はこのような問題が本来 不得手であり，一般に応力解析およびそれをもとにした誤 差解析の精度は非常に悪い。ただし，特異性の強さを求め るための $\mathrm{J}$ 積分值や応力拡大係数を計算する際に有限要素 法が用いられるので，ここでは特に例題として取り上げる ことにした。

さて, 今 Fig. 16 に示すように，クラックを有する正方形 板が一様引き張り応力 $s$ を受けているとする。数值パラメ ータは次のように設定した。

$$
a=2 \quad w=8 \quad s=1 \quad E=10000 \quad \nu=0.3
$$
この問題に対する初期有限要素モデルとして, Fig. 17 の対 


$E=10000$
$\nu=0.3$
$a=4$
$w=8$
$\mathrm{~S}=1$

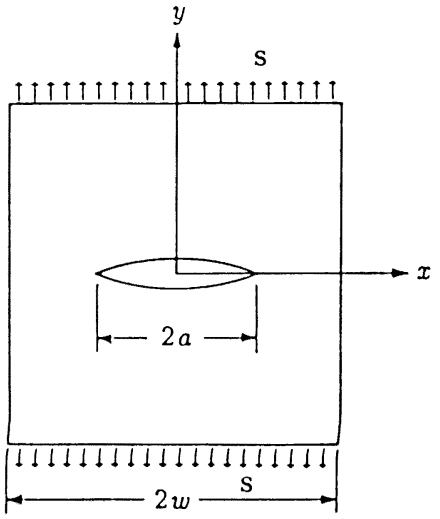

Fig. 16 Square plate with crack

$M E S H-G$ (original)

64 Elements

81 Nodes S

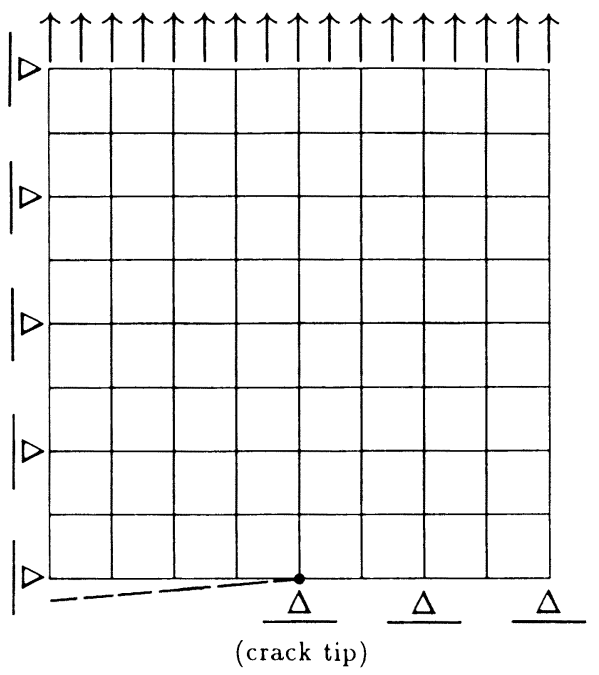

Fig. 17 Original finite element model

称性を考慮した 4 節点要素で構成される等分割モデル $M E S H-G$ を用いる。

激しい応力変化が起こる $y=0$ 上の $\sigma_{y}$ の分布を Fig. 18 に破線で示す。この問題は㦑密にクラックの先端で応力が 無限大になるべきであるが，通常の 4 節点要素を用い，さ らにこのような粗い要素分割の場合, 十分に応力のピーク を表現できていない。

同様のモデル $(M E S H-G)$ の場合について, 応力解析結

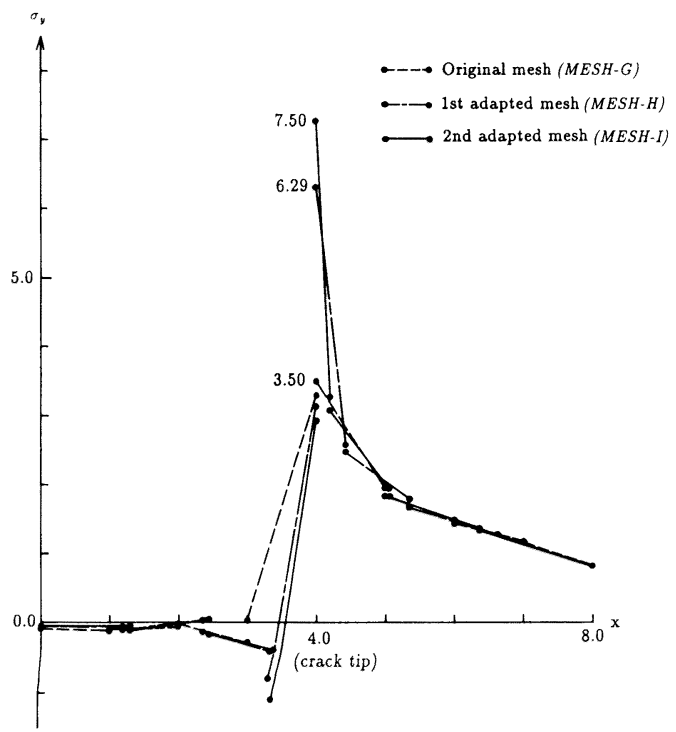

Fig. 18 Stress distributions along the $\mathrm{x}$-axis

$$
\|e\|_{i} / \sqrt{\text { area }_{i}} \quad \begin{gathered}
\text { Original mesh } \\
\text { (MESH-G) }
\end{gathered}
$$

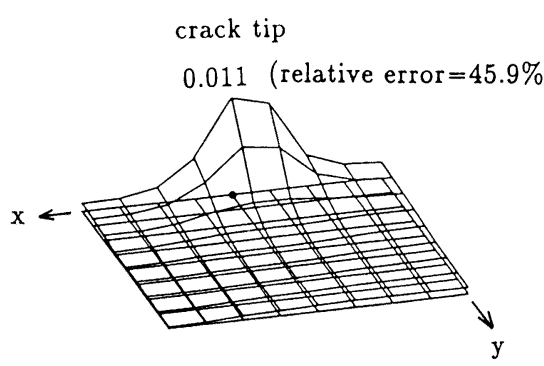

Fig. 19 Estimated error distributions for the original mesh

Table 2 Stress intensity factors

\begin{tabular}{|l|c|c|}
\cline { 3 - 3 } \multicolumn{2}{c|}{} & $K_{I}$ \\
\hline \multirow{3}{*}{ FEM } & $M E S H-G$ (original) & 3.85 \\
\cline { 2 - 3 } & $M E S H-H(1$ st adapted) & 4.05 \\
\cline { 2 - 3 } & $M E S H-I$ (2nd adapted) & 4.11 \\
\hline Exact. & 4.19 \\
\hline
\end{tabular}

果をもとに, ERRAND-FEM を用いて事後誤差評価を行 つた。Fig. 19 は解析された各要素の誤差のエネルギーノル 么を要素面積の平方根で割ったもの，すなわち単位面積当 たりの誤差の分布をプロットしたものである。クラックの 先端で相対誤差にして $45.9 \%$ になる大きな誤差が発生 していることがわかる。また，領域全体での相対誤差は $21.0 \%$ であると評価された（Table 3)。なお，厳密にはク 
ラック先端での誤差も無限大になるべきであるが，応力解 析の場合と同様の理由で, 誤差のピークも十分に表現され ていない。

次にこの事後誤差評価結果を用いて，前節と同様の手順 で要素再分割を行った結果をFig. 20(a)に示す $(M E S H$ $H)$ 。再分割の際の境界条件は，モデルのコーナー部ならび にクラック先端上の節点は移動させない, その他の境界上 の節点はモデル境界上のみを移動させる，というものとし た。この図から，誤差が大きくなるクラック先端に節点が 集中していることがわかる。ここで，特異点であるクラッ ク先端を含要素に関しては重み $W_{i}^{m}$ をえる $(7)$ 式中 のpの值を 0.5 とした。これは, 要素に特異点が含まれる 場合, 本要素の事前誤差解析による誤差ノルムの収束が $O\left(h^{0.5}\right)$ になるためである ${ }^{14)} 。 こ の M E S H-H$ を用いて応 力解析を行った結果を Fig. 18 に一点鎖線で示す。クラッ ク先端での応力のピークがオリジナルの 3.50 から 6.29 に 上昇したことがわかる（Table 2)。

本例題ではさらに MESH-H をもとにして, 2 度目の要 素再分割を行った。新たに得られた再分割モデルを Fig. 20 (b)に示す $(M E S H-I) 。 M E S H-H$ に比較してさらにク ラック先端に節点が集中していることがわかる。この MESH-I を用いて応力解析を行った結果をFig. 18 に実 線で示す。クラック先端での応力のピークがさらに上昇し, 同じ要素数でありながら， 7.50 とオリジナルモデルの約 2.14 倍にもなった。このことから，本方法による順応型要 素分割により，より妥当な応力解析が行えるようになった ということができる。

次にこの有限要素解析結果を用いて応力拡大係数 $K_{I}$ 在 求めた值を比較する。Table 2 はクラック先端にもっとも 近いクラック上の節点での有限要素解から求められた $K_{I}$

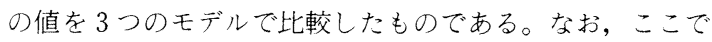
$K_{I}$ を求める際には変位法 ${ }^{15)}$ を用いた。また， $E_{x a c t}$ ，として 示した值は, 石田の解析解 ${ }^{15)}$ である。要素再分割の結果, 応 力のピークだけでなく応力拡大係数もより解析解に近い妥 当な值となっていることがわかる。

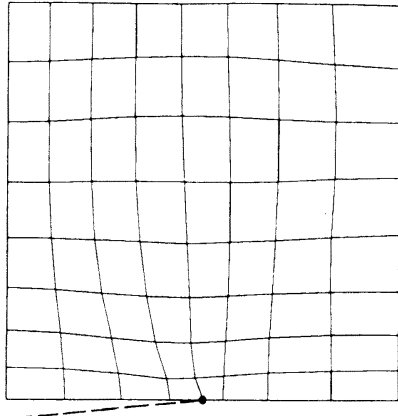

(crack tip)

(a)

ただし, 本例題の場合, Table 3 に示されているように要 素再分割の結果, クラック先端での応力のピークは上昇し たものの，解析領域全体での誤差は減少せず，3つのモデ ル共にほぼ同じ值である。これは，モデルが改善されるに したがって特異点周辺での応力解析の精度が向上すると上 もに，誤差解析の精度も向上され，本来無限大になる心゙き クラック先端での誤差がより正確に評価されるようになっ たためであると考えられる。Fig. 21 は MESH-I を用いた 場合の単位面積当たりの䛊差分布をプロットしたものであ る。この図から，クラック先端での誤差詊価值がオリジナ

Table 3 Estimated relative error and maximum stress for the plate with a crack problem

\begin{tabular}{|c|c|c|}
\cline { 2 - 3 } \multicolumn{1}{c|}{} & $\|\mathrm{e}\| /\|u\|$ & $\left(\sigma_{y}\right)_{\max }$ \\
\hline MESH-G(original) & $21.0 \%$ & 3.50 \\
\hline MESH-H(1st adapted) & $20.3 \%$ & 6.29 \\
\hline MESH-I(2nd adupted) & $22.0 \%$ & 7.50 \\
\hline
\end{tabular}

crack tip

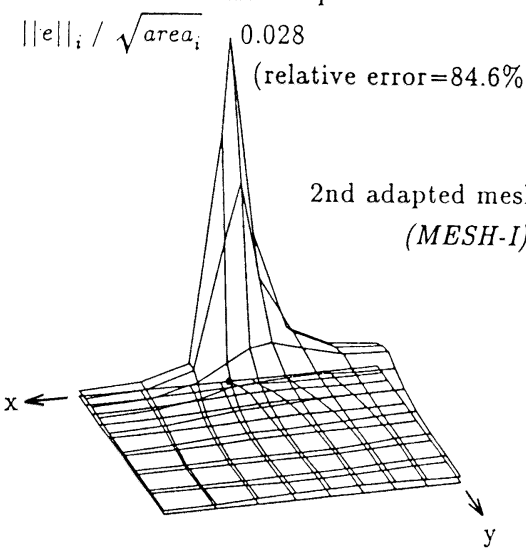

Fig. 21 Estimated error distributions for the 2nd adapted mesh

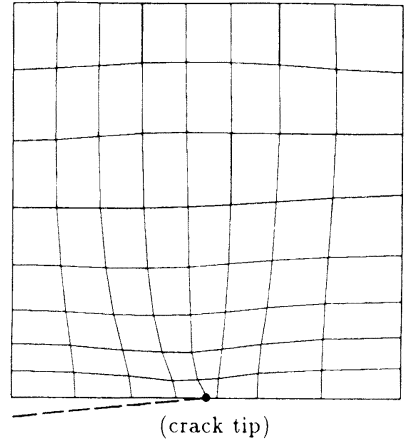

(b)
MESH-I(2nd adapted) 64 Elements 81 Nodes

Fig. 20 1st and 2nd adapted finite element models 
ルモデル $(M E S H-G)$ に比べて大きくなっていることがわ かる。それにもかかわらず領域全体での誤差分布がそれほ よ゙上昇していないということは，MESH-Iにおけるクラ ック先端部以外の領域での䜋差が， $M E S H-G$ に比較して 相対的に小さくなっているということである。

以上のことから，このような特異点を含む問題に対して も, 本論文の方法による順忍型要素分割は, $\mathrm{J}$ 積分值や応力 搪大係数を正確に求める手段等として有効であると結論で きる。

\section{7. おわりに}

本論文は，ERRAND-FEMによる事後誤差評価結果を もとにした， $r$-methodによる順応型要素分割法に関する 研究を行ったものである。本論文で新たに提案された要素 再分割法の妥当性, 有効性が $2 つ 0$ 適用例により示された。 いずれの場合に扔いても， 厂学的な知識をまったく用いな い均等分割の有限要素モデルをもとにして，モデルによっ て異なる值をとるパラメータを用いることなしに, 経験豊 かなエキスパートが作成したような有限要素モデルを得る ことができた。そして，この順応型有限要素モデルを用い ることによって, 要素の自由度を変化させずに誤差の減少 や，応力ピークの上昇といったより信頼性の高い有限要素 解を得ることができた。

本方法のフレキシビリティとシンプルさを利用して, 今 後は

（1）より大型かつ複雑な問題への適用

(2) 3 次元問題, 板殻問題への適用ならびに高次要素を 用いたモデルへの適用

を行い,さらには要素形状の歪みが大きくなった場合には

(3) 自動的な $h$-method との組み合わせ

が行えるようにする必要があると考えられる。ここで用い たスムージングという方法はあくまで補助的なものであ り, 今後は要素形状と誤差の定量的な関係を導くための研 究がぜひ必要となってくるだろう。いずれにせよ

「より信頼性の高い有限要素解をより効率的に得ること」が われわれのめざすシステムの目標の 1 つであり, 本論文で 提案した順応型要素分割法がその目標のための 1 ステップ となることが期待される。

\section{参 考 文献}

1）矢川元基, 吉村忍, 中尾和弘, 曽根田直樹：あいま い知識処理手法による 3 次元自動要素分割, 構造工 学における数值解析法シンポジウム論文集, 第 13 巻, 日本鋼構造協会, (平成元年 7 月), pp. 53-58。

2）角洋一,林重年：4 分木自動分割法のき裂進展経路シ
ミュレーションへの応用, 構造工学における数值解 析法シンポジウム論文集, 第 13 巻, 日本鋼構造協会, (平成元年 7 月), pp. 41-46。

3）大坪英臣：有限要素法の最近の動向（その1)-誤差 評価と順応型要素分割-, 日本造船学会誌, 第 683 号, (昭和 61 年 5 月), pp. 21-32。

4) D. W. Kelly : The Self-Equilibration of Residuals and Complementary A Posteriori Error Estimates in the Finite Element Methodu, Int. J. Num. Meth. Eng., Vol. 20, (1984), pp. 1491-1506.

5）岡田哲男：船体構造に適した自動要素分割法, 造船 設計における構造解析と信頼性工学シンポジウム, 日本造船学会, pp. 21-39。

6) 大坪英臣, 北村充 : 有限要素による平面応力問題の 誤差評価と応力修正に関する研究, 日本造船学会論 文集，第 165 号，(平成元年 6 月), pp. 225 232。

7) 大坪英臣, 北村充 : 2 次元応力集中問題有限要素解 の誤差評価と要素再分割, 日本機械学会論文集 (A 編), (平成 2 年掲載予定)。

8) H. Ohtsubo and M. Kitamura: Element by Element A Posteriori Error Estimation and Improvement of Stress Solutions for Two-Dimensional Elastic Problems, Int. J. Num. Meth. Eng., (Vol. 29, (1990), pp. 223-244.

9) A. R. Diaz, N. Kikuchi and J. E. Taylor: A Method of Grid Optimization for Finite Element Methods, Computer Meth. Appl. Mech. Eng., Vol. 41, (1983), pp. 29-45。

10) P. Ladeveze, G. Coffignal and J. P. Pelle: Accuracy of Elastoplastic and Dynamic Analysis, Accuracy Estimates and Adaptive Refinements in Finite Element Computations, Chapter 11, John Wiley \& Sons Ltd., (1986), pp. 181-203.

11） O.C. ツィエンキーヴィッツ著, 吉識雅夫・山田喜昭 監訳：マトリックス有限要素法, 三訂版, 培風館, 1984, pp. 35-36。

12) Y. Kodama: Thee-Dimensional Grid Generation around a Ship Hull Using the Geometrical Method, J. Soc. Nav. Arch. of Japan, Vol. 164, pp. 1-8.

13）谷口健男, 太田親：複数個のき裂進展挙動解析のた めの要素自動分割法, 構造工学における数値解析法 シンポジウム論文集, 第 13 巻, 日本鋼構造協会, (平 成元年 7 月), pp. 47-52。

14) B. A. Szabo: Estimation and Control of Error Based on $p$ Convergence, Accuracy Estimates and Adaptive Refinements in Finite Element Computations, Chapter 3, John Wiley \& Sons Ltd., (1986), pp. 61-78.

15）鷿津久一郎他編: 有限要素法ハンドブック（応用 編), 培風館, 1983, pp. 326-330。 